Citation: Özdemir, O. \& Kayhan, F. (2019). The Effect Of Global Financial Crisis On Securities Portfolio Of Deposit Banks: A Difference-In-Differences Method For Turkey, BMIJ, (2019), 7(1): 444466 doi: http://dx.doi.org/10.15295/bmij.v7i1.1082

\title{
THE EFFECT OF GLOBAL FINANCIAL CRISIS ON SECURITIES PORTFOLIO OF DEPOSIT BANKS: A DIFFERENCE-IN- DIFFERENCES METHOD FOR TURKEY
}

Onur ÖZDEMIR ${ }^{1}$

Fatih KAYHAN ${ }^{2}$
Received Date (Başvuru Tarihi): 20/01/2019

Accepted Date (Kabul Tarihi): 02/03/2019

Published Date (Yayın Tarihi): 25/03/2019

ABSTRACT

This study analyzes the effects of the global financial crisis of 2008 upon public and private deposit banks' securities portfolio in Turkey for the quarterly period between 2005 (Q1) and 2015 (Q4). Difference-in-Differences (DiD) method is employed to solve the research question of this paper, which is whether or not there exist a significant change in differences between Turkish public and private banks' ratio of securities (financial assets) to total assets during and after the crisis. This study concludes by suggesting that after the global financial crisis, securities to assets ratio of publicly owned deposit banks significantly differed from that of privately owned ones in Turkey.Compared to the private deposit banks, there has been a significant decrease in the specified ratio of public deposit banks. This can be explained by taking into account the very nature of public banks. The results of the econometric analyses indicate that after the crisis, unlike the private deposit banks, state-owned deposit banks held fewer securities in their total assets in Turkey, which is in line with the behavior of lending more to eliminate the negative effects of the crisis of 2008.

Keywords: Securities Portfolio, Public and Private Deposit Banks, Banking Behavior, Global Financial Crisis, Difference-in-Differences (DiD) Method

JEL Codes: F65, P10, E25

\section{KÜRESEL FINANSAL KRİZIN MEVDUAT BANKALARININ MENKUL KIYMETLER PORTFÖYÜNE ETKILERİ: TÜRKIYYE İÇINN DIFFERENCE-IN- DIFFERENCES METODU}

\section{$\ddot{O} Z$}

Bu çalışma, 2008 küresel finansal krizinin, 2005 (Ç1) ve 2015 (Ç4) arası çeyrek dönemde Türkiye'de kamu ve özel mevduat bankaları üzerindeki etkilerini incelemektedir. Çalışmanın araşttrma sorusu, kamu ve özel sermayeli mevduat bankalarinın 2008 Küresel Finans Krizi aninda ve sonrasinda finansal varlik/toplam varlı oraninda istatistiksel olarak anlaml derecede bir değişim olup olmadiğl, Difference-in-Differences (DiD) yaklaşımı ile çözülmektedir. Çalışmanın sonuçları göstermektedir ki; Türkiye'de kamu sermayeli mevduat bankalarının toplam varliklarına oranla menkul kiymetler portföyü toplamı, küresel finansal kriz sonrasinda özel sermayeli mevduat bankalarından önemli ölçüde farklıdır. Özel sermayeli mevduat bankalarına klyasla kamu sermayeli mevduat bankalarının belirtilen oranlarında önemli bir düşüş yaşanmıştır. Bu sonuç, kamu bankalarının kendine özgü nitelikleri ile izah edilebilir. Ekonometrik analiz sonuçları Türkiye'de kriz sonrasında kamu bankalarının aktiflerinde özel sermayeli mevduat bankalarının aksine daha az sayıda menkul kiymet bulundurduğunu ve 2008 krizinin olumsuz etkilerini ortadan kaldırmak için daha fazla borç verme davranışına uygun olduğunu göstermektedir.

Anahtar Kelimeler: Menkul Klymetler Portföyü, Özel ve Kamu Sermayeli Mevduat Bankaları, Bankacıllk Davranışı, Küresel Finansal Kriz, Difference-in-Differences (DiD) Metodu

JEL Kodlart: F65, P10, E25

\footnotetext{
${ }^{1}$ Asst. Prof., Istanbul Gelisim University, International Trade (English) Department, onozdemir@gelisim.edu.tr, http://orcid.org/0000-0002-3804-0062

${ }^{2}$ Dr., MetLife, Finance Specialist, fatih.kayhan06@gmail.com, http://orcid.org/0000-0001-7844-8663
} 


\section{INTRODUCTION}

In a free market economy, it can be stated that there is a close relationship between the overall health of the economy and the banking system. Banking activities and more specifically banking behaviors are highly influential in economic conditions. In this vein, the banking system plays an important role as financial intermediaries to provide the necessary amount of resources to individuals who have a shortage. Therefore, the financial sector as a whole still strictly depends on the functions of the banking system. Since banks use different types of financial instruments and thus provide the flow of funds among economic agents, they constitute the most important pillar of money transfers in the financial sector. However, it should be also mentioned that due to the technological progress in the banking system, banks do not limit themselves only with the transfer of excess money available in their accounts in line with the above-mentioned process, but also perform a wide range of financial transactions.

Traditional wisdom on the theory of banking defines the role and behavior of banks in the most abstract form as follows: it is an institution and/or organization which carries out the collection of deposits from individuals and then lends them to the public to make transactions of economic needs more easily. This definition is very strict in itself since lawmakers use it to decide whether or not they are subject to the legislation of any financial intermediary. However, the modern banking theory divides the functions of banks into four major categories (Freixas and Rochet, 2008): (i) providing access to the payment system; (ii) asset transfer; (iii) risk management; and (iv) information process and tracking of indebted people.

In addition, from a much different and wider perspective, the importance of bank behavior can be evaluated through their dimensions and social impacts of bank activities. For instance, when the macroeconomic conditions are examined, it was observed that the effects of banks' intermediation activities had a significant effect on the overall health of the economy between 2004-2008 period within the context of monetary and credit developments in the Eurozone. Therefore, it shows that the analysis of money and credits in terms of their growth rates is of great importance for performing of an appropriate monetary policy. In that sense, judging by the role of banking behavior in terms of monetary policies, it can be posted as one of the most crucial determinants of credit developments. Hence, ignoring the role of banking attitudes and behaviors of banks can be meant that banks as financial intermediaries have a passive role in an aggregate economy in which it makes their major positions in the emergence of financial crises should not be excused (European Central Bank, 2011). 
A deposit bank collects deposits and provides lending to individuals, companies or holds its assets as a liquid or financial securities. During the non-crisis period, it is apparent that a deposit bank lends more instead of holding more assets in its balance sheet. However, during the economic and financial crisis, a deposit bank chooses to be liquid by holding more securities in its total assets instead of lending more due to the increase in repayment-risk of the loans provided. A privately-owned deposit bank may prefer this behavior with the only motivation for making more profit. Nevertheless, does a state-owned deposit bank behave in the same way? Or does it behave with different motivation and behave differently in crisis time by holding financial assets less in order to lend more in an effort to decrease the effects of the financial crisis? In that vein, this paper looks for an answer to the following question: Do publicly-owned banks behave counter-cyclically and hold financial assets less in comparison to their privately-owned rivals for the purpose of providing more loans to companies that need funding in crisis time? Taking the mission of a public bank into account, this is expected behavior from the publicly-owned bank which is, in the final analysis, a stateagent. This study is based on this theoretical argument.

By taking into account of the above-mentioned theoretical consideration in the context of the hypothetical question, the aim of this study is to determine whether or not the public deposit banks in Turkey behaved differently in comparison to private deposit banks in terms of holding financial assets after the global financial crisis determining the existence of difference in differences regarding the ratio of securities to total assets. Another way of saying, the focal point of this study is to determine whether or not state-owned deposit banks in Turkey behaved in a counter-cyclical way after the global financial crisis of 2008.

The contribution of this study to literature is that findings of the change in differences between public and private deposit banks' ratio of securities to total assets during and after the crisis are provided via econometric analysis for Turkish deposit banks by employing Difference-in-Differences (DiD) method.

Introduction part provides the basic information about the paper together with the motivation of this study. The rest of this paper is organized as follows. Section 2 covers the literature review. Turkish Banking Sector is covered in Section 3. Section 4 discusses the data, methodology and the econometric results. Section 5 concludes the article. 


\section{THEORETICAL CONSIDERATIONS ON FINANCE AND BANKING}

\section{SECTOR}

After the repayment difficulties about risky mortgage loans in the USA in 2007, the financial institutions that invested in financial assets and derivative products based on mortgage loans commenced facing financial difficulties. The bankruptcy of Lehman Brothers - leading investment bank at that time in the USA- gave rise to the start and escalation of the crisis that still has reflections on the world economies.

According to the Kindleberger and Aliber (2005), there are mainly three stages in the history of the financial crises which are ranged as manias (euphoria), panics and crashes, respectively. Related to these stages, the crash in the capitalist organization emerges as a decline of asset prices or more specifically, as the collapse of the banking system and/or firm structure. The crash brings further panics in an aggregate economy, especially in the financial sector, by negatively affecting the asset markets as a whole. A panic leads people to hold more reliable securities such as government securities which are less liquid. The increasing demand for less liquid government securities depends on the idea that the government has unlimited power to print more money. Therefore, the possibility for government bankruptcy is very nominal. Although this is the case for traditional wisdom of people who own these less liquid government securities, the financial crisis may emerge in other sectors or in the sectors where the government is also economically active (Kindleberger and Aliber, 2005: 94). Just before the panics and crash, the mania and the bubble emerge as a significant factor exacerbating the current problems in economic relations. Therefore, the word "mania" indicates irrationality and "bubble" ushers in that some values which will eventually burst (Kindleberger and Aliber, 2005: 25).

However, Beaud (2015: 190-191) specifies that the logic behind the financial crisis depends on the following conditions: (i) the raising $\operatorname{costs}^{3}$ and (ii) the shrinking of markets ${ }^{4}$ (including both real and financial markets). Independent from these two factors, the reasons behind the capitalist crises, especially emerging in the financial sector, can be extended within the context of different economic, social and political conditions. For instance, some crucial factors related to the economic sides of the conditions can be ranged as follows (Beaud, 2015: 191): (i) the decline of marketing prices; (ii) the realization problems of profits; and (iii) the severe competition across various markets.

\footnotetext{
${ }^{3}$ For instance, the increase in wages or the prices of trackages in the United States.

${ }^{4}$ For instance, the erosion of purchasing power in the agriculture, the decrease in the consumption level of workers, the reduction in government expenditures, or the problems that the foreign exchange markets have in transactions of money.
} 
Heilbroner and Milberg (1998: 8) also state that the manipulative activities emerging in financial transactions prepare the conditions of economic depression and thus lead to an increasing size of the impact of factors that cause to the emergence of the financial crisis. Following the stock market crash, the credit structure collapses and therefore individual investors are forced to sell out their stock to brokers to meet their indebtedness. The financial sector as a whole may suddenly become an insolvent which is highly engaged in risky foreign bonds. Hence, the policies pursuing by monetary authorities become unaffected to reform the financial sector. In that vein, Albertini et al. (1990: 98) rightfully underline the importance of parallelism between the prices of stocks and the development level of economic activities.

In addition to the details of specific areas of the financial sector, one can look at the economy politics of finance in order to understand the changes in the banking industry throughout the historical movement both for cross-country and within-country analyses. In that sense, the finance as a whole and the financial ingredients in a specific case can be understood within the case of financialization. It also led us to make sense about the crises emerging in the financial system. According to Arrighi ([1994]2010: 371), the financialization has always been the preface to the final crisis of the dominant regime of capital accumulation, that is, to its decadence and ended by a new phase of regime though it promotes its organizers to maintain their economic and political power. Güngen (2010: 86) argues that one of the major implication of Arrighi [1994] (2010)'s study can be found in its multi-functional explanation in case of financialization since it can be used as a tool for understanding the changes in the behavior of households and individuals. Furthermore, the term itself has been the basis for an explanation of the formation of investment both at national and international level (Güngen, 2010: 86). For instance, Kozanoğlu (2011: 14) argues that it is possible to point out the consensus about the fact that financialization is the last step of the historical process commenced with neoliberalism and continued with globalization. Therefore, to test the effects of different points of financial components on the social realm, the internal dynamics of these historical steps should be considered.

The comprehensive outlook for different implications about financialization is made by Epstein (2005) in which the role of finance capital strictly depends on the ingredients of both neoliberalism and globalization. The strict connection of these lead Epstein (2005: 3) to argue that financialization can be defined as an increasing role of financial motives, financial markets, financial actors and financial institutions in domestic economies and international economies as well. This kind of definition is also adopted by Krippner (2005: 176) and she 
complements the theoretical context of Epstein (2005) by referring to two controversial issues which are highly effective on the hypothetical inferences of financialization: (i) the issue on the management of firms and/or institutions; and (ii) the issue on the role of globalization in terms of the collapse of state autonomy. According to Krippner (2011: 4), these issues exacerbate the profit-making tendencies in economic activities to arise by way of financial channels in contrast to the productive activities. Therefore, the historical process is conducted on an increasing gap between the real and financial sectors ${ }^{5}$.

Dumenil and Lévy (2011) also point out that the financialization process cannot be considered separately from the neoliberalism and globalization phenomena, and thus emphasize that the impact of financialization on the socio-economic and political elements should be discussed interactively with the other two cases. However, they also note that the meaning of financialization includes duality in itself. Therefore, the financialization process can be evaluated in two cases. On the one hand, it can be defined as a focus on the financial institutions and the innovative procedures of the financial relations; on the other hand, it can also be taken as an understanding of administrative criteria such as the creation of the value a shareholder ought to have ${ }^{6}$ (Dumenil and Lévy, 2011: 35).

Milios and Sotiropoulos (2009) examine the potentials of economic crises within the case of an increasing scale of financialization in aggregate economic relations and thus share the almost same perspectives argued by Epstein (2005). However, the distinctive feature of their arguments from the others is based on the fact that they point out the role of neoliberal components in making an analysis about the recent changes in the financial system of different economies. According to Milios and Sotiropoulos (2009), four major factors determine the limits of financialization which can be ranged as follows: (i) the deregulation of labour markets; (ii) the liberalization of capital flows; (iii) the privatization of the public sector; and (iv) the increasing access to cheap credits.

Stockhammer (2004) examines the term of financialization on the basis of nonfinancial companies. As a matter of fact, according to Stockhammer (2004: 721), the financialization is defined as the integration of non-financial businesses into financial markets. In other words, the financial activities in an aggregate economy are investigated as the reflection of a shift in the firm's objectives and its motives and a rising impact of

\footnotetext{
${ }^{5}$ For more information about the relationship between capital accumulation and financialization, please also see Krippner (2004).

${ }^{6}$ In addition to these two definitions, comparable surplus rates and profit rates of the financial sector should be also included into the analysis. The boom in the components of financial management within the financial institutions and non-financial firms as well as the extraordinary increase in revenues paid to financial managers should be included into these investigations. For more details, please also see the older analyses of Dumenil and Lévy (2004a, 2004b).
} 
shareholder interests in the firm. For instance, related to this classification, Orhangazi (2008: 5-6) investigates the financialization phenomenon both at micro and macro levels. First, in the macro-dimension, financialization can be regarded as an increasing volume and importance of financial markets, institutions and transactions in the economic activities. Second, in the micro-dimension, financialization can be used to identify the changing relationship between non-financial institutions and financial markets. The first of these changes is the increase in financial investments and the increase in financial revenues of non-financial firms, and the second is the increasing pressure on the financial market-oriented management of nonfinancial firms.

Even though the increasing scale of finance has been influential on an aggregate economy in general, there were still some problems with defining the financialization ${ }^{7}$. This is very crucial since the changes in socio-economic structures of countries, especially covering emerging economies, have highly been affected by the increasing power of the financial sector on productive relations over time. Hence, some common arguments are needed to understand the changes in different phenomena emerging in the financial sector. For instance, Sweezy (1997) defines the financialization as a shift from the center of gravity of the capitalist system through production to finance which indirectly points on the complexity of economic activities ${ }^{8}$. Following the Sweezy (1997)'s argument, Foster (2010) focuses on the long-run determinants of financialization in the context of three basic characteristics of the economies: (i) the overall decline in growth rates; (ii) the increasing dominance of monopolistic/oligopolistic multinational corporations; (iii) the increasing impact of financial motives in capital accumulation. In addition, Foster (2010) specifies the changes occurring in case of financialization by looking at the following economic conditions: (i) increase in financial profits in total profits; (ii) rise of total debt in GDP; (iii) the growth of the share of finance, insurance and real estate (FIRE) sectors accruing in national income; (iv) the diversification of exotic and opaque financial instruments; and (v) the rise of the numbers of financial bubbles all over the world economies.

\footnotetext{
${ }^{7}$ Karaçimen (2015: 91) also classifies different types of effects of financialization by focusing on several economic phenomena: (1) for an investigation of financialization in terms of macroeconomic framework and its effects on capital accumulation within the context of center countries please see Dumenil and Levy (2004b), Stockhammer (2004), Crotty (2005) and Orhangazi (2007); (2) for an investigation of the arguments of social accounting approach and its term of "coupon pool capitalism" please see Froud et al. (2001) and Ertürk and Solari (2007); (3) for an investigation of the arguments on the maximization of shareholder value please see Aglietta (2000) and Boyer (2000); (4) for more individualistic investigations of financial expansion please see Martin (2002) and Langley (2008); and (5) for an investigation of the structural change of capitalism in terms of financialization within the frame of banking sector development and increasing household debts please see Dos Santos (2009), Ergüneş (2009) and Lapavitsas (2009a, 2009b, 2010b).

${ }^{8}$ To get a comprehensive outlook for the historical details on this issue, please see Sweezy (1991).
} 
Lapavitsas (2010a) also extends the above-mentioned components of financialization by using more specific details acquiring from the banking sector. According to Lapavitsas (2010a), the financial sector as a whole should be understood in case of a different framework since the financialization itself has a multi-conceptual context which is highly specific to the within-country factors. In essence, three fundamental trends have formed the basis of this new way of looking to the financialization. First, large companies were able to finance their own investments from non-distributed profits and were able to provide external financing, largely out of the open market, which has been weakened the dependency on the banking sector. Second, the banks have transformed their loans by transferring available credits to the individuals besides the firms. Third, workers have been increasingly linked to the financial system which has led them to change their behaviors towards being much reliable to the borrowing and financial gains and has increased the size effects of the economic downturns.

Paincheira (2008), on the other hand, states that the acceleration of financialization, based on developing countries, has great effects on their economies. In particular, Paincheira (2008), who addresses the case of international capital flows, explores the financialization impact on these countries in the presence of two issues. First, the high rates of current account deficits as part of GDP result in financial and foreign exchange crises. Second, the international reserves are very high level in those countries. The factors that the international reserves depend on are basically formed by two distinctive issues which are protectionism and the real depreciation in foreign exchange rates exacerbated by the increasing scale of protectionism. Moreover, as an additional factor, it can be necessarily pointed out that the increasing degree of economic integration in global financial markets is effective in making reserve accumulation in these countries. This approach produced by Paincheira (2008) is highly significant due to the fact that it shows the effects of reserve accumulation on north and south distinction of economies. The accumulation of reserves essentially leads the direction of capital transfer from developing countries to developed countries and hence increases the economic impact of the public sector. The importance of the current issue in the context of financialization is basically due to the fact that the countries which have reserve surplus have the power to provide funds to the countries which have deficits in their reserves by different kinds of financial instruments and also have an important role in the development path of the financial relations.

The multifaceted perspectives on financialization were also been maintained by Dore (2002) and Wade (2005). First, Dore (2002) discusses the effects of financialization on 
institutional change. Therefore, financialization needs to be interactive with different fields. According to Dore (2002: 116-117), they can be listed as follows: (i) the condition of financial controls within the firm management; (ii) the ratio of total assets to financial assets; (iii) the ratio of financial assets to marketed bonds and stocks; (iv) the importance of stock exchange and business cycles for internal control in determining firm strategy; and (v) increasing dominance of financial sector in total economic activity. Second, Wade (2005) discusses the financialization in the context of the relationship between the real sector and the financial sector. According to Wade (2005), the increasing hegemony of financial sector on the real sector constitutes one of the most important components of the recent period which is based on three factors: (i) reinforcing the corporate ties and normative matching within the interests of wealth owners; (ii) the redistribution of national income towards the capital owners; and (iii) the redistribution of total income in favour of the highest $\% 1$ and $\% 10$ percentiles of households.

However, Kotz (2008) has avoided defining the changing role of finance as part of an increasing hegemony of the financial sector. Instead of using this kind of hegemony relations as a concept in defining the changing financial relations, Kotz (2008) has preferred the term of financialization which was far-reaching to get more information on the growing role of finance in an aggregate economy. Kotz (2008) has further stated that the increasing scale of financialization constitutively hinges on the neoliberal restructuring. Therefore, Kotz (2008) has reversed the causality relationship between financialization and neoliberalism. In that vein, according to Kotz (2008), the financialization has been widened the distinction between non-financial activities and finance as a whole but also has led to the emergence of both qualitative and quantitative differences in the financial sector.

Related to the problems in economic structure, Albo et al. (2010), for instance, deal with financialization in case of both internationalization of capital ${ }^{9}$ and economic crises. According to Albo et al. (2010: 40-41), the subordination of capital on the national level increases together with an increasing scale of financialization which is imposed as an external limit for the autonomous world market. In particular, Glyn (2006) states that the privileged position of the financial sector depends on both the aggregate demand and individual firm behavior. Hence, consumers have no obligation to make a decision under the limits of budget constraint. In that vein, the new role of the financial markets is conditioned on three basic tools which transform the scope of financialization as well: (i) the increasing control on firm's

\footnotetext{
${ }^{9}$ This is similar to the arguments of Sweezy and Magdoff (1972) in which they pointed on the increasing power of financial sector as a major indicator to understand the monopolization tendencies.
} 
administration; (ii) the power to reduce costs; and (iii) the potential to maximize short-term profits $^{10}$.

To be a more specific issue about the financialization, one can also focus on the components of the banking sector. For instance, holding securities as a part of liquidity behavior should be analyzed together with lending behavior. This is due to the fact that deposit banks' assets are comprised mainly of cash and cash equivalents (including reserves), securities and loans. If a bank prefers to increase lending, then it is to decrease liquid assets and/or securities. Therefore, a deposit bank is in a position to be more liquid by holding more liquid assets and financial assets or to lend more in the face an external shock (an economic financial crisis). Another way of saying, lending more means holding fewer securities and liquid assets.

As far as Turkey is concerned, the following studies analyze the impact of the crisis on the difference between the lending behavior of public and private banks. Kok and Ay (2013) and Marois and Güngen $(2014 ; 2016)$ analyze Turkish banking system together with the crisis and state that public banks lend more than private banks in the global financial crisis of 2008.

A liquid asset to total assets ratio and securities to total assets ratio are used as liquidity ratios measuring the banks' liquidity behavior. Mihaljek (2010), Sanya ve Mlachila (2010) argue that in crisis times banks (ignoring the difference between publicly owned or privately-owned banks) tend to increase liquidity. Examining developing countries for the period from 2002-2009, Mihaljek (2010) analyses banking intermediary during the peak level of 2008 global financial crisis and reaches out the following findings; in developing countries the banks adjust themselves to the crisis (balancing their financial conditions according to the crisis), increase public debt instruments in their securities portfolio and decrease asset duration for the purpose of remaining more liquid. When we look at the determinants of the liquidity, we see that required reserve ratio has a significant effect on liquidity. Alper et al. (2016) analyze Turkish banks for the years between 2010-2015 in order to find the interaction between required reserve ratio and lending and thus maintain that the requires reserve ratio affects funding need and liquidity of the banks, in return the change in liquidity need has significant impact on lending behavior. On the other hand, high loans to deposit ratio is another determinant of the liquidity ratio on account of the fact that the ratio restrains liquidity.

\footnotetext{
${ }^{10}$ Husson (2010: 22) explains the financialization through profit making and value creation. In that token, the financial markets strengthened by financialization does not create any value. On the contrary, the profits produced in the real sector are generated by the leakages from the production.
} 


\section{TURKISH BANKING SECTOR}

When the basic functions of the banking sector are examined, it is apparent that they perform three distinct roles in the economic and financial system (Yüksel et al., 2004). The first is the trust. Investors essentially lend their money to the highly credible borrowers. This is what the banks should have in principle. The second is the transfer. The banks are the major units to collect the deposits from people. The third is the transformation. One of the most important conflicts of interests between the borrower and the creditor is the duration of the loan and in this sense, the banks act as a bridge between two parties. Most of them convert short-term deposits into short- and medium-term loans.

For instance, the total size of the asset statement of the banking sector increased by approximately $18.2 \%$ at the end of 2015 in Turkey, which tells us that the total amount is 2.357 billion Turkish Lira. The size of a total asset as part of GDP is $1.01 \%$ at the end of $2015^{11}$. In addition, the distribution of the types of loans indicates that the share of commercial and corporate loans is $48 \%$, the share of SME loans is $26 \%$ and the share of individual loans ${ }^{12}$ is $26 \%$ in total loans, respectively.

Moreover, according to the Main Indicators Report of Banking Regulation and Supervision Agency (BRSA) for 2015 (December), the size of the balance sheet shows that the ratio of foreign assets and liabilities to total assets and liabilities is $38 \%$ and $45 \%$, respectively. When we look at the Turkish Lira (TL) and Foreign Currency (FX) distinction of loans, FX loans in total loans have a weight of $32 \%$. On the other hand, when the TL and FX weight in the total deposits is analyzed, it can be seen that the foreign currency deposit in total deposits is $43 \%$. In this context, it is important to examine the effect of the 2008 crisis and its aftermath on the banking sector ${ }^{13}$.

From 2005 to 2015, deposit banking assets comprise approximately $96 \%$ of the total conventional banking industry (total of deposit banking and development-investment banking) and public deposit banking assets comprise $31 \%$ of total deposit banks assets. Therefore, it can be stated that public deposit banking assets compose nearly one-third of conventional (deposit) commercial banks.

According to the Turkish Banking Sector Main Indicators Report issued by BRSA in June 2018 indicates that there are 52 banks operating in Turkey, which are classified as 34

\footnotetext{
11 At the end of 2017 , it was increased to the $1.05 \%$.

${ }^{12}$ Individual loans consist of the total amount of consumer loans and credit cards.

${ }^{13}$ In particular, it should be noted that the return on equity and the capital adequacy are featured as the major factors in the overall health

of the growth of the banking sector in Turkey.
} 
deposit banks, 13 development and investment banks, and 5 participation banks. The report also notes the following details on the banking sector in Turkey:

- A number of branches realized as 11.598 and the number of personnel realized as 208.878 .

- Total securities realized as 432 billion TL (11.8\% of total banking assets) as of end2017. This figure was 330 billion TL (14\% of total banking assets) as of December 2015.

- When it comes to allocation of securities, it is seen that June-2018 figures are as follows: government bonds comprise 66\%, Eurobonds 24\%, Sukuk 3\% (non-interest rent certificates issued by the Treasury) and others $7 \%$.

All in all, Table 1 shows the total assets and liabilities of the banking sector in June 2018. As seen from Table 1, the total assets of the banking sector went up by $12.7 \%$ to 3.672 billion TL as of June 2018. This is very crucial to have an idea about the general health of the banks and more specifically, of the financial sector. Figure 1 below indicates a statistically significant change in the differences between the Turkish public and private deposit banks' securities ratio (financial assets/total assets) after-crisis period.

Table 1. Total Assets of the Banking Sector, June 2018

\begin{tabular}{ccc}
\hline \hline Assets & Total (Billion TL) & Change (Previous End of Year) \\
\hline Cash and Cash Equivalents ${ }^{14}$ & 295 & $12.8 \%$ \\
Required Reserves & 261 & $15.1 \%$ \\
Loans & 2,353 & $12.1 \%$ \\
Non-Performing Loans (Gross) & 74 & $14.9 \%$ \\
Securities & 432 & $7.5 \%$ \\
Other Assets & 331 & $22.6 \%$ \\
\hline Total Assets & $\mathbf{3 , 6 7 2}$ & $\mathbf{1 2 . 7 \%}$ \\
\hline \hline Liabilities & Total (Billion TL) & Change (Previous End of Year) \\
\hline Deposits & 1899 & $11.0 \%$ \\
Due to Banks & 581 & $22.3 \%$ \\
Funds from Repo Transactions & 210 & $112.9 \%$ \\
Securities Issued & 176 & $20.9 \%$ \\
Equities & 395 & $9.9 \%$ \\
Other Liabilities & 411 & $-12.4 \%$ \\
\hline Total Liabilities & $\mathbf{3 , 6 7 2}$ & $\mathbf{1 2 . 7 \%}$ \\
\hline \hline
\end{tabular}

\footnotetext{
${ }^{14}$ Sum of cash, receivables from Central Bank, Money Market and Banks items.
} 




Public Private

Figure 1. Total Securities / Total Assets (2005-2015, Quarterly Period)

(Deposit Banking Sector)

Source: BRSA

\section{DATA, METHODOLOGY AND EMPIRICAL RESULTS}

The data is collected from the official database of BRSA. The data obtained from BRSA covers all public and private deposit banks for the period between 2005 and 2015 . However, the sample period is formed as quarterly. In this sense, the total number of bank observations is 88 for the selected sample period ${ }^{15}$. The following analyses for the selected sample are based on the financial ratios which are released on the relevant database of BRSA in a uniform set as quarterly.

The major reason why we choose the year 2005 as the beginning period of analysis is due to the fact that 2005 is the year of regulatory changes occur in inflationary accounting in principle. In addition, to have standard data in all quarters, the year 2005 is chosen as the first date that the analysis is based on. Furthermore, considering the recovery period of four years just after the 2001 banking crisis in Turkey, we argue that the year of 2005 would be the most preferable year to select in order to obtain robust and significant results from the analysis. Finally, the availability of the selected data for the whole period precisely starts with the year of 2005 .

${ }^{15}$ (Public + Private Banks) $* 44$ quarter periods. 
In this study, a dummy variable is used to control for ownership type of the deposit banks in Turkey which include both public banks and private banks. To control for the effect of the crisis on the bank lending behavior, two dummies are employed in the analysis. They include crisis and after-crisis variables which describe the crisis period between 2007 (Q4) and 2009 (Q2) and the period after the crisis, respectively. The dependent variable is the total (net) financial assets divided by the total assets. The dependent variable is the security ratio which is used in the traditional literature on the banking sector. Table 2 shows the details on the list of control variables.

Table 2. List of Control Variables

\begin{tabular}{ccc}
\hline \hline Variable & The Classification of Dummies & Source \\
\hline crisis & The Crisis Period (2007Q4-2009Q2) & NBER \\
aftercrisis & The Period After the Crisis (2009Q2-2015Q4) & NBER \\
\hline Variable & Banking Industry (Ownership) Type & Source \\
\hline public & Publicly Owned Deposit Banks Dummy Variable & BRSA \\
\hline \hline
\end{tabular}

Furthermore, Table 3 provides the summary statistics for the ratio of financial assets to total assets as well as the liquidity ratio and loans to assets ratio.

Table 3. Summary Statistics

\begin{tabular}{cccccc}
\hline Ratios & Obs & Mean & St. Dev. & Min. & Max. \\
\hline loans / total assets (\%) & 88 & $49.6 \%$ & 0.11 & $20.8 \%$ & $63.3 \%$ \\
liquid assets / total assets (\%) & 88 & $8.2 \%$ & 0.03 & $2.8 \%$ & $13.2 \%$ \\
financial assets (net) / total assets (\%) & 88 & $27.9 \%$ & 0.11 & $13.3 \%$ & $48.3 \%$ \\
\hline \hline
\end{tabular}

In this study, the crisis period is taken as a quarterly covering from 2007 (Q4) to 2009 (Q2) on the grounds that NBER indicates December 2007 and June 2009 as the last peak and deep levels for the expansion and the contraction of business conjunctures, respectively. In addition to this conceptualization about the crisis, we also choose that period since the CDS premiums have reached very high levels which were over 200. 
The sample includes all public and private deposit banks in Turkey. The econometric technique that we choose to use in the following analysis is based on panel data method. In that sense, we deal with the effect of the global financial crisis on securities portfolio of deposit banks through the fixed effects model.

As a research question, we are concerned about whether or not there exists a significant change in differences between Turkish public and private banks' ratio of financial assets to total assets after the crisis. To test this research question, we utilize from DiD method. DiD is used to compare the differences of treatment and control groups after a natural experiment and then is used to estimate the application impacts of a natural experiment. In other words, DiD method is essentially an impact analysis which investigates the before-andafter periods relationship among variables ${ }^{16}$. In this study, the global financial crisis is treated as the natural experiment which started in 2008.

To test the hypothesized research question, we consider the following econometric model in equation, which is used apply DiD method in the analysis:

$$
\mathrm{SEC}_{\mathrm{it}}=\beta_{\mathrm{o}}+\beta_{\mathrm{cr}} \mathrm{D}_{\mathrm{cr}}+\beta_{\mathrm{pcr}} \mathrm{D}_{\mathrm{p}} \mathrm{D}_{\mathrm{cr}}+\beta_{\mathrm{afcr}} \mathrm{D}_{\mathrm{afcr}}+\beta_{\mathrm{pafcr}} \mathrm{D}_{\mathrm{p}} \mathrm{D}_{\mathrm{afcr}}+\mu_{1} \mathrm{tq}+\mu_{2} \mathrm{tq}_{\mathrm{p}}+\alpha_{\mathrm{i}}+\varepsilon_{\mathrm{it}}
$$

where SEC refers to securities portfolio which is estimated by total (net) financial assets divided by total assets; $D_{p}$ refers to dummy variables for the public banks; $D_{\text {cr }}$ refers to dummy variables for the only-crisis period, i.e. 2007Q4-2009Q2; $\mathrm{D}_{\text {afcr }}$ refers to dummy variables for the after-crisis period, i.e. 2009Q3-2012Q4; $\beta_{\mathrm{o}}$ constant term; tq refers to time trend; $\mu$ refers to the coefficient of time trend; $\alpha_{i}$ accounts for the fixed effects; $i$ refers to observation unit and $t$ refers to time. $\varepsilon_{\text {it }}$ stands for the matrix of error terms.

The econometric analysis is built on the Standart Error Correction Method produced by Driscoll and Kraay (1998) since the diagnostic tests show that there exist serial correlation, heteroskedasticity and cross-sectional dependency between the series. In addition, the F-tests and the Hausman tests indicate that random effects or pooled OLS estimations are not proper for the data and thus the fixed effects method is selected for the analysis.

Quarter fixed-effects are not included in the analysis due to the fact that trend and dummy variables related to the crisis periods are already incorporated into the model. If quarter fixed-effects are included, this might cause some statistical problems such as multicollinearity. The separate analyses of the (only) crisis period and after-crisis period

\footnotetext{
${ }^{16}$ For more information on DiD method, please see Gropp et al. (2014) and Adams-Kane et al. (2014) who analyze the banking behavior.
} 
makes it available to take the specific effects of the only-crisis period into account, which consist of seven quarters starting from 2007Q4 to 2009Q2. Table 4 shows the period intervals for crisis dummy variables.

Table 4. Period Intervals for the Analysis

\begin{tabular}{lccc}
\hline \hline Crisis Analysis & $\begin{array}{c}\text { 2005Q1-2007Q3 } \\
\text { Before-Crisis }\end{array}$ & Crisis & 2007Q4-2009Q2 \\
\hline (Only) Crisis & 0 & 1 & 0 \\
(After) Crisis & 0 & 0 & 1 \\
\hline \hline
\end{tabular}

We build the analysis around the following hypotheses whether or not a DiD exists to determine the structure of the following hypotheses.

For the only-crisis period, the hypotheses are structured as follows:

$H_{0:}$ There is no change in differences between public and private banks' securities ratio during the crisis period.

$\boldsymbol{H}_{1}$ : There is a (significant) change in differences between public and private banks' securities ratio during the crisis period.

As far as the after-crisis period is concerned, the following hypotheses are built as follows:

Ho: There is no change in differences between public and private banks' securities ratio after the crisis period.

$\boldsymbol{H}_{1}$ : There is a (significant) change in differences between public and private banks' securities ratio after the crisis period.

All in all, the preliminary analysis below shows a considerable change in the differences between public and private deposit banks' securities portfolio in Turkey, following the 2008 Global Financial Crisis. Table 5 shows basic DiD regression results and indicates a statistically significant change in differences between public and private deposit banks' securities ratio after-crisis period, which include the sample of all public and private conventional deposit banks in Turkey from 2005 to 2015 on a quarterly basis. The regressions are based on only bank ownership type (public and private banks) dummy variables and the crisis dummy variables. The term "crisis*public" explains the interaction of only-crisis period 
and the public bank. On the other hand, the term "aftercrisis*public" accounts for the interaction of the after-crisis period and the public bank. The variable "tq*public" refers to the interaction of time trend and public banks.

Table 5. Baseline Regression Results for Basic DiD Analysis

(Dependent Variable: Total (Net) Financial Assets / Total Assets)

\begin{tabular}{|c|c|}
\hline Variables & Regression Results \\
\hline \multirow[t]{2}{*}{ crisis } & $0.0761 * *$ \\
\hline & $(0.0297)$ \\
\hline \multirow[t]{2}{*}{ aftercrisis } & $0.139 * * *$ \\
\hline & $(0.0403)$ \\
\hline \multirow[t]{2}{*}{ crisis*public } & -0.0161 \\
\hline & $(0.00981)$ \\
\hline \multirow[t]{2}{*}{ aftercrisis*public } & $-0.0385^{* *}$ \\
\hline & $(0.0152)$ \\
\hline \multirow[t]{2}{*}{ tq*public } & $-0.00473 * * *$ \\
\hline & $(0.000347)$ \\
\hline \multirow[t]{2}{*}{ tq } & $-0.00581 * * *$ \\
\hline & $(0.000936)$ \\
\hline \multirow[t]{2}{*}{ Constant } & $1.844 * * *$ \\
\hline & $(0.000936)$ \\
\hline No. of observations & 88 \\
\hline No. of groups & 2 \\
\hline
\end{tabular}

Note:Standard errors in parentheses, $* * * \mathrm{p}<0.01, * * \mathrm{p}<0.05,{ }^{*} \mathrm{p}<0.1$

DiD results are summarized in Table 6. The basic DiD analysis is conducted by using only "crisis status" and "bank ownership type". The table indicates a significant change in securities ratio of public deposits in Turkey in comparison to the private deposit banks aftercrisis period. As far as the only-crisis period is concerned, there exists no significant change in public deposit banks' ratio when compared to private deposit banks' ratio despite the negative sign. That is to say, after the crisis -on average- there is a considerable decline in public deposit banks' securities ratio when compared to private deposit banks' securities ratio. 
Table 6. Summary of Basic DiD Analysis

\begin{tabular}{ccc}
\hline \hline Period & Securities & Method \\
\hline (Only) Crisis Period (3 Period Analysis) & - & DiD \\
(After) Crisis Period (3 Period Analysis) & $-* *$ & DiD \\
\hline \hline
\end{tabular}

Note: (+) Positive (-) Negative (*) Significance Level $(* * * \mathrm{p}<0.01, * * \mathrm{p}<0.05, * \mathrm{p}<0.1)$

\section{CONCLUSION}

In this study, we examine the effect of the global financial crisis of 2008 on the securities portfolio of both public and private deposit banks in Turkey. We specifically analyze whether or not the bank ownership type matters regarding the effect of the crisis on the ratio of financial assets to total assets. Therefore, the focal point of this study is whether or not securities to assets ratio of public deposit banks significantly change as opposed to private rivals (during and) after the global financial crisis for the sample of all public and private deposit banks operating in Turkey between 2005 and 2015 on a quarterly basis. In other words, the existence of a significant change in differences between public and private deposit banks' ratio of financial assets to total assets after the global financial crisis is analyzed in an effort to determine if public deposit banks behaved in a counter-cyclical manner (by lending more and holding less financial assets) in the face of the crisis.

Previous studies about the impact of the global financial crisis indicate that both public and private banks -on average- prefer to be liquid and to limit lending. However, literature also shows that public banks behave differently than private banks in that they lend more instead of holding more liquid assets plus financial assets during and after the global financial crisis. In other words, state-run banks are found to lend more instead of holding more liquid assets and securities when compared to private rivals. This very fact is in line with public banks' counter-cyclical behaviors.

As regards Turkish deposit banking sector, according to the data analyses conducted here, it is concluded that -on average- public deposit banks hold fewer securities (in comparison to their total assets) than private counterparts after the global financial crisis of 2008. The results are in line with the lending figures in Turkey where the public deposit banks lend more than private ones during and after the global financial crisis. In view of the specific characteristics and structures of state banks, their major aim is not just making more profit, rather they operate for the purpose of supporting lending in order to get rid of the negative 
effects of the crisis on an aggregate economy. This becomes available only if public banks hold less financial assets (i.e., a significant decrease in the ratio of financial assets to total assets) than private banks. 


\section{REFERENCES}

Adams-Kane, J., Caballero, J., and Lim J. (2014). Foreign Bank Behavior during Financial Crises.InterAmerican Development Bank Working Paper Series, No. IDB-WP-512.

Aglietta, M. (2000). Shareholder value and corporate governance: some tricky questions.Economy and Society, 29(1), 146-159.

Albertini, J. M., Pecherand, M. and Poujet, M. (1990). Ekonomik Sistemler: Uygulamada Kapitalizm ve Sosyalizm. Uludağ University Consolidation Foundation No. 48, U.U FEAB The Economics of Business Administration and Accounting Research and Application Center Publication No. 49, Translated by Prof. Dr. Cafer Unay, Uludağ: Uludağ University Press.

Albo, G., Gindin, S. and Panitch, L. (2010). In and Out of Crisis: The Global Financial Meltdown and Left Alternatives. Oakland: Spectre PM Press.

Alper, K., Binici, M., Demiralp, S., Kara, H., and Ozlu, P. (2016). "Reserve Requirements, Liquidity Risk, and Bank Lending Behavior”.Koç University-TUSIAD Economic Research Forum Working Paper, No. 1612.

Arrighi, G. [1994] (2010). The Long Twentieth Century: Money, Power, and the Origins of Our Times. London, New York: Verso.

Beaud, M. (2015). Kapitalizmin Tarihi 1950-2010. Translated by Fikret Başkaya, Istanbul: Yordam Book.

Boyer, R. (2000). "Is a Finance-led growth regime a viable alternative to Fordism? A preliminary analysis".Economy and Society, 29(1), 111-145.

Crotty, J. (2005). The Neoliberal Paradox: The Impact of Destructive Product Market Competition and 'Modern' Financial Markets on Nonfinancial Corporation Performance in the Neoliberal Era.Financialization and the World Economy, in Gerald Epstein (ed.), 77-110, Cheltenham, UK and Northampton, MA, USA: Edward Elgar.

Dore, R. (2002). “Stock Market Capitalism and its Diffusion”.New Political Economy, 7(1), 115-121.

Dos Santos, P. (2009). "At the Heart of the Matter: Household Debt in Contemporary Banking and the International Crisis".Research on Money and Finance, Discussion Paper Series, No: 11.

Driscoll, J. C. andKraay, A. C. (1998).“Consistent Covariance Matrix Estimation with Spatially Dependent Panel Data".Review of Economics and Statistics, 80(4), 549-560.

Dumenil, G. and Lévy, D. (2004a). “The Real and Financial Components of Profitability (United States, 19522000)".Review of Radical Political Economics, 36(1), 82-110.

Dumenil, G. and Lévy, D. (2004b). Capital Resurgent: Roots of the Neoliberal Revolution. Cambridge, Massachusetts and London: Harvard University Press.

Dumenil, G. and Lévy, D. (2011). The Crisis of Neoliberalism. Cambridge, Massachusetts and London: Harvard University Press. 
Epstein, G. (2005b). Financialization and the World Economy. Gerald Epstein (ed.), Cheltenham, UK and Northampton, MA, USA: Edward Elgar.

Ergüneş, N. (2009). “Global Integration of the Turkish Economy in the Era of Financialisation”.Research on Money and Finance, Discussion Paper Series, No: 8.

Ertürk, I. and Solari, S. (2007). “Banks as Continuous Reinvention”.New Political Economy, 12(3), 369-388.

European Central Bank. (2011).“The Supply of Money-Bank Behaviour and the Implications for Monetary Analysis".Monthly Bulletin, 63-79, October.

Foster, J. B. (2010). “The Financialization of Accumulation”.Monthly Review, 62(5), October.

Freixas, X., and Rochet, J. C. (2008). Microeconomics of Banking. Cambridge: The MIT Press.

Froud, J. H., Haslam, C., Johal, S. and Williams, F. (2001). "Financialisation and the Coupon Pool".Gestao ve Producao, 8(3), 271-288.

Glyn, A. (2006). Capitalism Unleashed: Finance Globalization and Welfare. Oxford, New York: Oxford University Press.

Gropp, R., Gruendl, C., and Guettler, A. (2014).“The impact of public guarantees on bank risk-taking: Evidence from a natural experiment”. Review of Finance, 18(2), 457-488.

Güngen, A. R. (2010). "Finansallaşma: Sorunlu bir Kavram ve Verimli bir Araştırma Gündemi”.Praksis, 20, 85108.

Heilbroner, R. and Milberg, W. (1998). The Making of Economic Society. 10 ${ }^{\text {th }}$ edition, New Jersey, Upper Saddle River: Prentice-Hall.

Husson, M. (2010). Marksist İktisat Teorisi: Çăgdaş Kapitalizm ve Kriz. $1^{\text {st }}$ edition, Istanbul: Yazın Publishing.

Karaçimen, E. (2015). Türkiye’de Finansallaşma: Borç Klskacında Emek. $1^{\text {st }}$ edition, Istanbul: Sosyal Araştırmalar Vakfi Publishing.

Kindleberger, C. P., and Aliber R. Z. (2013). Manias, Panics and Crashes: A History of Financial Crisis. London: Palgrave Macmillan.

Kok, D. and Ay, O.E. (2013). "2008 Küresel Finansal Krizinin Türk Bankacıllk Sektörü Etkinlik Düzeylerine Yansıması Üzerine Bir Araştırma”.Uluslararası İktisadi İdari İncelemeler Dergisi,10, 155-170.

Kotz, D. M. (2008).Neoliberalism and Financialization.Amherst: University of Massachusetts Press.

Kozanoğlu, H. (2011). Finansallaşma ve Türkiye. Uç(ur)amayan Balon, in Hayri Kozanoğlu (ed.), $1^{\text {st }}$ edition, 11-59, Istanbul: Ayrıntı Publishers.

Krippner, G. R. (2004). “What Is Financialization?”.mimeo, Department of Sociology, UCLA.

Krippner, G. R. (2005). “The financialization of the American economy”.Socio-Economic Review, 3(2), 173 208.

Krippner, G. R. (2011). Capitalizing on Crisis: The Political Origins of the Rise of Finance. Cambridge, Massachusetts and London: Harvard University Press. 
Langley, P. (2008). The Everyday Life of Global Finance: Saving and Borrowing in Anglo-America. Oxford, New York: Oxford University Press.

Lapavitsas, C. (2009a). "Financialised Capitalism: Crisis and Financial Expropriation”.Historical Materialism, 17(2), 114-148.

Lapavitsas, C. (2009b).'Financialisation, or the Search for Profits in the Sphere of Circulation".Research on Money and Finance, Discussion Papers No: 10.

Lapavitsas C. (2010a). "Banks for the People”.Redpepper, Issue: 170, February/March.

Lapavitsas, C. (2010b). "Financialisation and Capitalist Accumulation: Structural Accounts of the Crisis of 2007-9".Research on Money and Finance, Discussion Papers No: 16.

Marois, T., and Güngen A.R. (2014). “Türkiye’nin devlet bankalarını geri kazanmak”.Iktisat Dergisi,527, 54-70.

Marois, T. andGüngen, A. R. (2016). "Credibility and class in the evolution of public banks: The case of Turkey".Journal of Peasant Studies,43(6), 1285-1309.

Martin, R. (2002). Financialization of Daily Life. Philadelphia: Temple University Press.

Mihaljek, D. (2010). "Domestic bank intermediation in emerging market economies during the crisis: Locally owned versus foreign-owned banks”. BIS Papers, 54, 31-48.

Milios, J. and Sotiropoulos D. P. (2009).Financialization: Market Discipline or Capital Discipline? Rethinking Imperialism: A Study of Capitalist Rule, in John Milios and Dimitris P. Sotiropoulos (eds.), London: Palgrave Macmillan.

Orhangazi, Ö. (2007). "Financialization and Capital Accumulation in the Non-Financial Corporate Sector: A Theoretical and Empirical Investigation of the U.S. Economy: 1973-2003”.Political Economy Research Institute, Working Paper Series No: 149, University of Massachusetts, Amherst.

Orhangazi, Ö. (2008). Financialization and the US Economy. Cheltenham, UK and Northampton, MA, USA: Edward Elgar.

Paincheira, J. P. (2009). "Finansallaşma Çağında Gelişmekte Olan Ülkeler: Açık Birikiminden Rezerv Birikimine".Translated by Sabriye Biçen,Maliye ve Finans Yazıları, 1(82).

Sanya, O.S. and Mlachila, M. (2010). “Post Crisis Bank Behavior: Lessons from Mercosur”.International Monetary Fund Working Paper,WP/10/1.

Stockhammer, E. (2004). "Financialisation and the slowdown of accumulation".Cambridge Journal of Economics, 28(5), 719-741.

Sweezy, P. M. (1991). “Monopoly Capital After Twenty-Five Years”.Monthly Review, 43(7), December.

Sweezy, P. M. (1997). “More (or less) on Globalization”. Monthly Review, 49(4), September.

Sweezy, P. M. and Magdoff, H. (1972). Economic History as it Happened, Volume 1 (The Dynamics of U.S. Capitalism: Corporate Structure, Inflation, Credit, Gold, and the Dollar). London, New York: Monthly Review Press. 
Wade, H. R. (2005). "The March of Neoliberalism and What to Do About It". draft paper for plenary talk at conference Beyond 'Deregulation': Finance in the 21st Century, University of Sussex, 26-28 May.

Yüksel, A. S., Yüksel A., and Yüksel Ü. (2004). Bankacılık Hukuku ve Işsletmesi.Istanbul: Beta Publishing. 